\title{
PENGARUH SERTIFIKASI GURU DAN MOTIVASI KERJA GURU \\ TERHADAP KINERJA GURU SMA NEGERI 1 SENTOLO \\ KABUPATEN KULON PROGO TAHUN 2012
}

\section{Oleh :}

\author{
Risma Istiarini ${ }^{1}$
}

Sukanti ${ }^{2}$

\begin{abstract}
Abstrak
Penelitian ini dilakukan dengan tujuan untuk mengetahui : (1) Pengaruh Sertifikasi Guru terhadap Kinerja Guru SMA Negeri 1 Sentolo Kabupaten Kulon Progo Tahun 2012, (2) Pengaruh Motivasi Kerja Guru terhadap Kinerja Guru SMA Negeri 1 Sentolo Kabupaten Kulon Progo Tahun 2012, (3) Pengaruh Sertifikasi Guru dan Motivasi Kerja Guru terhadap Kinerja Guru SMA Negeri 1 Sentolo Kabupaten Kulon Progo Tahun 2012.

Subjek dalam penelitian ini adalah 45 Guru di SMA Negeri 1 Sentolo Kabupaten Kulon Progo. Penelitian yang dilakukan adalah penelitian populasi. Objek penelitian berupa Sertifikasi Guru, Motivasi Kerja Guru dan Kinerja Guru. Penelitian dilakukan pada bulan Februari sampai Maret 2012. Teknik pengumpulan data dengan menggunakan angket. Uji validitas menggunakan rumus product moment, dan uji reliabilitas menggunakan rumus koefisien alpha. Sebelum melakukan analisis data, dilakukan uji linieritas dan uji multikolonieritas. Analisis data menggunakan regresi sederhana dan regresi ganda.

Hasil penelitian menunjukan bahwa : (1) terdapat pengaruh positif dan signifikan Sertifikasi Guru terhadap Kinerja Guru SMA Negeri 1 Sentolo Kabupaten Kulon Progo dengan koefisien korelasi (r) 0,410, koefisien determinasi $\left(\mathrm{r}^{2}\right)$ 0,618, dan harga t hitung 2,952 lebih besar dari t tabel 1,99; (2) terdapat pengaruh positif dan signifikan Motivasi Kerja Guru terhadap Kinerja Guru SMA Negeri 1 Sentolo Kabupaten Kulon Progo Tahun 2012 dengan koefisien korelasi (r) 0,537, koefisien determinasi $\left(\mathrm{r}^{2}\right)$ 0,288, dan harga t hitung 4,173 lebih besar dari t tabel 1,99; (3) terdapat pengaruh positif dan signifikan Sertifikasi Guru dan Motivasi Kerja Guru terhadap Kinerja Guru SMA Negeri 1 Sentolo Kabupaten Kulon Progo Tahun 2012 dengan koefisien korelasi (R) 0,560, koefisien determinasi $\left(\mathrm{R}^{2}\right)$ 0,314, dan harga $\mathrm{F}$ hitung 9,6 03 lebih besar dari $\mathrm{F}$ tabel 3,230. $\mathrm{X}_{1}$ memberikan sumbangan efektif sebesar $7,62 \%$ dan $\mathrm{X}_{2}$ memberikan sumbangan efektif sebesar $23,75 \%$.
\end{abstract}

\footnotetext{
${ }^{1}$ Alumni Program Studi Pendidikan Akuntansi UNY

2 Dosen Jurusan Pendidikan Akuntansi UNY
} 


\section{A. Pendahuluan}

Dewasa ini pendidikan di Indonesia semakin dimajukan dengan pesat. Pendidikan yang diharapkan yaitu pendidikan yang modern dan bermutu untuk menciptakan bangsa yang cerdas dan intelek. Pendidikan yang bermutu memiliki kaitan ke depan dan ke belakang. Kaitan ke depan berupa pendidikan yang bermutu merupakan syarat utama untuk mewujudkan bangsa yang maju, modern, makmur, dan sejahtera. Sejarah perkembangan dan pembangunan bangsa-bangsa mengajarkan pada kita bangsa yang maju, modern, makmur, dan sejahtera adalah bangsa-bangsa yang memiliki sistem dan praktik pendidikan yang bermutu. Kaitan ke belakang bahwa pendidikan yang bermutu sangat tergantung pada keberadaan guru yang bermutu, yakni guru yang profesional, sejahtera, dan bermartabat.

Pemerintah dalam rangka meningkatkan mutu pendidikan nasional melalui peningkatan komponen mutu guru, telah meluncurkan program sertifikasi guru. Sertifikasi guru adalah pemberian sertifikat kepada para guru yang telah memenuhi standar profesional guru. Pemerintah berharap dari program sertifikasi ini kinerja guru akan meningkat sehingga pada akhirnya, mutu pendidikan akan meningkat pula. Masih banyak guru SMA N 1 Sentolo yang sudah bersertifikasi tetapi belum sesuai dengan kemampuan seorang guru yang bersertifikasi atau tercapainya Kinerja Guru yang baik setelah sertifikasi.

\section{B. Metode Penelitian}

Penelitian ini merupakan penelitian kuantitatif karena penelitian ini banyak menggunakan angka-angka, mulai dari pengumpulan data, penafsiran terhadap data tersebut, serta penampilan dari hasil penelitian ini pun diwujudkan dalam angka. Selain itu, penelitian ini merupakan penelitian expost-facto karena data yang diperoleh adalah data hasil dari peristiwa yang sudah berlangsung, sehingga peneliti hanya mengungkap fakta berdasarkan pengukuran gejala yang telah ada pada responden. Penelitian ini juga merupakan penelitian kausal komparatif, karena penelitian ini bertujuan untuk mengetahui kemungkinan adanya hubungan sebab akibat dengan cara tertentu berdasar atas pengamatan terhadap akibat yang ada, kemudian mencari kembali faktor yang diduga menjadi penyebabnya, melalui pengumpulan data. Penelitian ini juga termasuk penelitian populasi, karena subjeknya meliputi semua yang terdapat di dalam populasi.

Metode pengumpulan data dalam penelitian ini data diperoleh dengan metode survei dengan teknik pengumpulan data kuesioner. Kuesioner merupakan teknik pengumpulan data 
yang dilakukan dengan cara memberikan beberapa pertanyaan atau pernyataan tertulis kepada responden untuk dijawabnya (Sugiyono, 2008). Teknik analisis data yang digunakan adalah sebagai berikut :

\section{Uji Prasyarat Analisis}

a. Uji Linieritas

Uji ini digunakan untuk mengetahui apakah masing-masing variabel bebas sebagai prediktor mempunyai hubungan linier atau tidak dengan variabel terikat. Uji linieritas yang digunakan adalah uji $\mathrm{F}$ signifikan 5\%. Selanjutnya $\mathrm{F}_{\text {hitung }}$ dikonsultasikan dengan $\mathrm{F}_{\text {tabel }}$ pada taraf signifikan 5\%. Apabila $F_{\text {hitung }}$ lebih besar atau sama dengan $F_{\text {tabel }}$ maka terdapat hubungan linier antara variabel bebas terhadap variabel terikat. Jika $\mathrm{F}_{\text {hitung }}$ lebih kecil $\mathrm{F}_{\text {tabel }}$ maka hubungan antara variabel bebas terhadap variabel terikat tidak linier. Adapun rumus yang digunakan dalam uji linieritas :

$$
\mathrm{F}=\frac{R k_{r e g}}{R k_{r e s}}
$$

Keterangan :

$$
\begin{array}{ll}
\mathrm{F} & =\text { Harga bilangan regresi } \\
R k_{\text {reg }} & =\text { Rerata kuadrat garis regresi } \\
R k_{\text {res }} & =\text { Rerata kuadrat residu }
\end{array}
$$

Dengan pedoman sebagai berikut :

Jika $F_{\text {hit }}>F_{\text {tabel }}$, maka pengaruh tidak linier

Jika $F_{\text {hit }} \leq F_{\text {tabel }}$, maka pengaruh linier

b. Uji Multikolinieritas

Dilakukan sebagai syarat digunakannya analisis regresi ganda untuk mengkaji terjadi atau tidaknya multikolonieritas antar variabel bebas dengan menyelidiki besarnya korelasi antar variable tersebut. Uji Multikolonieritas ini menggunakan rumus korelasi Product Moment dari Pearson. Syarat tidak terjadinya multikolinieritas adalah harga interkorelasi antar variabel bebas $<0,800$. Apabila harga interkorelasi antar variabel bebas $\geq 0,800$ berarti terjadi multikolinieritas dan analisis data tidak dapat dilanjutkan. 


\section{Pengujian Hipotesis}

a. Analisis Bivariat

Analisis ini digunakan untuk mengetahui pengaruh sertifikasi guru terhadap Kinerja Guru dan pengaruh motivasi kerja terhadap Kinerja Guru. Adapun langkah-langkahnya adalah sebagai berikut:

1) Mencari koefisien korelasi antara variabel $X$ dan variabel $Y$

Korelasi Product Moment dari Pearson, yaitu sebagai berikut:

$r_{x y}=\frac{N \sum X Y-\left(\sum X\right)\left(\sum Y\right)}{\sqrt{\left(N \sum X^{2}-\left(\sum X\right)^{2}\right)\left(N \sum Y^{2}-\left(\sum Y\right)^{2}\right)}}$

Keterangan:

$\mathrm{r}_{\mathrm{xy}}=$ koefisien korelasi antara variabel $\mathrm{X}$ dan $\mathrm{Y}$

$\sum \mathrm{X}=$ jumlah variabel $\mathrm{X}$

$\sum \mathrm{Y} \quad=$ jumlah variabel $\mathrm{Y}$

$\sum \mathrm{XY}=$ jumlah perkalian antara variabel $\mathrm{X}$ dan variabel $\mathrm{Y}$

$\sum \mathrm{X}^{2} \quad$ jumlah kuadrat dari variabel $\mathrm{X}$

$\sum \mathrm{Y}^{2} \quad$ jumlah kuadrat dari variabel $\mathrm{Y}$

$\mathrm{N} \quad=$ jumlah responden

(Suharsimi, 2010: 213)

2) Mencari persamaan garis regresi dengan satu prediktor

$\mathrm{Y}=\mathrm{aX}+\mathrm{k}$

Keterangan :

$\mathrm{Y}=$ kriterium $\quad \mathrm{a}=$ bilangan koefisien

$\mathrm{X}=$ prediktor $\mathrm{k} \quad$ = bilangan konstan

(Sutrisno Hadi,2000:33)

3) Mencari koefisien determinasi $\left(r^{2}\right)$ antara prediktor $X_{1}$ dan $X_{2}$ dengan $Y$ dengan rumus sebagai berikut:

$r_{(1)}^{2}=\frac{a_{1} \sum x_{1} y}{\sum y^{2}}$

$r_{(2)}^{2}=\frac{a_{2} \sum x_{2} y}{\sum y}$

Keterangan:

$\mathrm{r}_{(1,2)}^{2}=$ koefisien determinasi antara $\mathrm{Y}$ dengan $\mathrm{X}_{1}$ dan $\mathrm{X}_{2}$ 
$\sum \mathrm{x}_{1} \mathrm{y}=$ jumlah produk antara $\mathrm{X}_{1}$ dengan $\mathrm{Y}$

$\sum \mathrm{x}_{2} \mathrm{y}=$ jumlah produk antara $\mathrm{X}_{2}$ dengan $\mathrm{Y}$

$\mathrm{a}_{1} \quad=$ koefisien prediktor $\mathrm{X}_{1}$

$\mathrm{a}_{2} \quad=$ koefisien prediktor $\mathrm{X}_{2}$

$\sum \mathrm{y}^{2} \quad$ = jumlah kuadrat kriterium $\mathrm{Y}$

(Sutrisno, 2004: 22)

4) Menguji keberartian regresi sederhana dengan uji t.

Uji t digunakan untuk mengetahui signifikansi antar variabel dependen. Adapun rumus uji t adalah :

$$
\mathrm{t}=\frac{\sqrt{\mathrm{r} n-2}}{\sqrt{1-\mathrm{r}^{2}}}
$$

Keterangan :

$\mathrm{t} \quad=$ nilai $\mathrm{t}$ hitung

$\mathrm{r} \quad=$ koefisien korelasi

$\mathrm{n} \quad$ = jumlah sampel

(Sugiyono, 2007 :230)

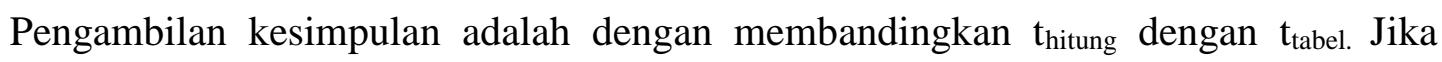
$t_{\text {hitung }}$ lebih besar atau sama dengan dari $t_{\text {tabel }}$ dengan taraf signifikansi 5\%, maka variabel tersebut berpengaruh secara signifikan. Sebaliknya, jika $t_{\text {hitung }}$ lebih kecil dari $t_{\text {tabel }}$ maka variabel tersebut tidak berpengaruh secara signifikan.

b. Analisis Multivariat

Analisis ini digunakan untuk mengetahui pengaruh Sertifikasi Guru dan Motivasi Kerja Guru terhadap Kinerja Guru. Dengan teknik regresi ganda akan diketahui indeks korelasi ganda dari kedua variabel bebas terhadap variabel terikat, koefisien determinan serta sumbangan relatif dan sumbangan efektif masing-masing variabel bebas terhadap variabel terikat.

Langkah-langkah analisis regresi ganda adalah:

1) Membuat persamaan garis regresi 2 prediktor

Rumus:

$Y=a_{1} X_{1}+a_{2} X_{2}+k$ 
Keterangan:

Y

$$
=\text { kriterium }
$$

$\mathrm{X}_{1}, \mathrm{X}_{2}=$ prediktor 1 , prediktor 2

$$
\begin{array}{ll}
\mathrm{a}_{1}, \mathrm{a}_{2} & =\text { bilangan koefisien } 1, \text { bilangan koefisien } 2 \\
\mathrm{k} & =\text { bilangan konstan }
\end{array}
$$

(Sutrisno, 2004: 18)

2) Mencari koefisien determinan antara kriterium $Y$ dengan prediktor $X_{1}$ dan $X_{2}$

Rumus:

$r_{y(1,2)}^{2}=\frac{a_{1} \sum x_{1} y+a_{2} \sum x_{2} y}{\sum y^{2}}$

Keterangan:

$\mathrm{r}_{\mathrm{y}(1,2)}^{2}=$ koefisien determinasi antara $\mathrm{Y}$ dengan $\mathrm{X}_{1}$ dan $\mathrm{X}_{2}$

$\mathrm{a}_{1} \quad=$ koefisien prediktor $\mathrm{X}_{1}$

$\mathrm{a}_{2} \quad=$ koefisien prediktor $\mathrm{X}_{2}$

$\sum \mathrm{x}_{1} \mathrm{y}=$ jumlah produk antara $\mathrm{X}_{1}$ dan $\mathrm{Y}$

$\sum \mathrm{x}_{2} \mathrm{y}=$ jumlah produk antara $\mathrm{X}_{2}$ dan $\mathrm{Y}$

$\sum \mathrm{y}^{2} \quad=$ jumlah kuadrat kriterium $\mathrm{Y}$

(Sutrisno, 2004: 22)

3) Menguji signifikansi regresi ganda dengan uji $\mathrm{F}$

Rumus:

$$
F_{\text {reg }}=\frac{R^{2}(N-m-1)}{m\left(1-R^{2}\right)}
$$

Keterangan:

$$
\begin{array}{ll}
\mathrm{R}_{\text {reg }} & =\text { harga } \mathrm{F} \text { garis regresi } \\
\mathrm{N} & =\text { cacah kasus } \\
\mathrm{m} & =\text { cacah prediktor } \\
\mathrm{R} & =\text { koefisien korelasi antara kriterium dengan prediktor }
\end{array}
$$

(Sutrisno, 2004: 23)

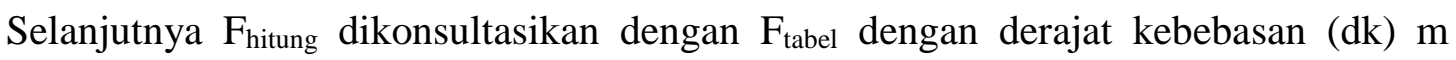
lawan N-m-1 pada taraf signifikansi 5\%. Apabila $F_{\text {hitung }}$ lebih besar atau sama dengan dari $\mathrm{F}_{\text {tabel, }}$ maka terdapat pengaruh yang signifikan antara variabel bebas terhadap variabel terikat. 
Jika $F_{\text {hitung }}$ lebih kecil dari $F_{\text {tabel, }}$, maka pengaruh variabel bebas terhadap variabel terikat tidak signifikan.

4) Mencari Sumbangan Relatif

a) Sumbangan Relatif (SR)

Sumbangan relatif adalah persentase perbandingan yang diberikan oleh suatu variabel bebas kepada variabel terikat dengan variabel-variabel bebas yang lain. Sumbangan relatif menunjukkan seberapa besar sumbangan secara relatif setiap prediktor terhadap kriterium untuk keperluan prediksi.

Rumus:

$S R \%=\frac{a \sum x y}{J K_{\text {reg }}} \times 100 \%$

Keterangan:

$\mathrm{SR} \%=$ sumbangan relatif dari suatu prediktor

a $\quad=$ koefisien prediktor

$\sum \mathrm{xy} \quad=$ jumlah produk antara $\mathrm{X}$ dan $\mathrm{Y}$

$\mathrm{JK}_{\text {reg }}=$ jumlah kuadrat regresi

(Sutrisno, 2004: 39)

b) Sumbangan Efektif (SE)

Sumbangan efektif adalah sumbangan prediktor yang dihitung dari keseluruhan efektifitas regresi yang disebut sumbangan efektif regresi. Sumbangan efektif digunakan untuk mengetahui besarnya sumbangan secara efektif setiap prediktor terhadap kriterium dengan tetap memperhitungkan variabel bebas lain yang tidak diteliti.

Rumus:

$S E \%=S R \% \times R^{2}$

Keterangan:

$\mathrm{SE} \%=$ sumbangan efektif dari suatu prediktor

$\mathrm{SR} \%=$ sumbangan relatif dari suatu prediktor

$\mathrm{R}^{2} \quad=$ koefisien determinasi

(Sutrisno, 2004: 39) 


\section{Hasil Penelitian dan Pembahasan}

\section{Uji Prasyarat Analisis}

Sebelum dilakukan analisis data terlebih dahulu dilakukan uji prasyarat analisis yang terdiri dari uji linieritas dan uji multikolonieritas.

a. Uji Linieritas

Uji linieritas hubungan dapat diketahui dengan menggunakan uji $\mathrm{F}$, yang dimaksudkan dengan uji $\mathrm{F}$ dalam analisis ini adalah harga koefisien $\mathrm{F}$ pada baris deviation from linearity yang tercantum dalam ANOVA Table dari output yang dihasilkan oleh SPSS versi 16.0. Selanjutnya nilai $\mathrm{F}$ dibandingkan dengan $\mathrm{F}$ tabel. Kriteria yang digunakan adalah garis regresi dikatakan linier jika koefisien F hitung lebih kecil dari F tabel. Selain itu untuk menghitung linieritas dapat diketahui juga dari nilai signifikansi nilai $\mathrm{F}$ hitung. Hubungan antara variabel bebas dan terikat dikatakan linier apabila signifikansi F lebih dari 0,05. Hasil uji linieritas hubungan dapat dilihat pada tabel berikut :

Tabel 1. Rangkuman Hasil Uji Linieritas

\begin{tabular}{|c|c|c|c|c|c|}
\hline Variabel Bebas & $\begin{array}{l}\mathrm{F} \\
\text { hitung }\end{array}$ & $\begin{array}{l}\mathrm{F} \\
\text { tabel }\end{array}$ & Kondisi & $\begin{array}{l}\text { Signi- } \\
\text { fikansi }\end{array}$ & Ket. \\
\hline $\begin{array}{lr}\text { 1.Sertifikasi } & \text { Guru } \\
\left(\mathrm{X}_{1}\right) & \text { dengan } \\
\text { Kinerja } & \text { Guru } \\
(\mathrm{Y}) & \\
\text { 2.Motivasi } & \text { Kerja } \\
\text { Guru } & \left(\mathrm{X}_{2}\right) \\
\text { dengan } & \text { Kinerja }\end{array}$ & 0,905 & 1,750 & $\mathrm{Fh}<\mathrm{Ft}$ & 0,576 & Linear \\
\hline Guru (Y) & 1,145 & 2,040 & $\mathrm{Fh}<\mathrm{Ft}$ & 0,370 & Linear \\
\hline
\end{tabular}

Berdasarkan tabel di atas, harga $\mathrm{F}$ hitung lebih kecil dari harga $\mathrm{F}$ tabel untuk masing-masing variabel pada taraf signifikansi 5\% sehingga dapat disimpulkan ada hubungan linier antara variabel dengan variabel terikat.

b. Uji Multikolonieritas

Uji multikolonieritas dimaksudkan untuk mengetahui data tidaknya multikolonieritas antar variabel bebas. Analisis regresi dapat dilakukan jika tidak terjadi multikolonieritas. Multikolonieritas tidak terjadi jika korelasi antar variabel bebas berharga kurang dari 0,800, 
Jurnal Pendidikan Akuntansi Indonesia, Vol. X, No. 1, Tahun 2012

Risma Istiarini \& Sukanti

Halaman $98-113$

berarti teknik analisis dapat dilanjutkan dengan menggunakan bantuan program komputer SPSS versi 16.0 yang disajikan dalam tabel berikut ini.

Tabel 2. Rangkuman Hasil Uji Multikolonieritas

\begin{tabular}{|l|l|l|l|}
\hline \hline Variabel bebas & $X_{1}$ & $X_{2}$ & Keterangan \\
\hline Sertifikasi Guru $\left(X_{1}\right)$ & 1 & 0.508 & Tidak multikolinier \\
Motivasi Kerja Guru $\left(X_{2}\right)$ & 0.508 & 1 & Tidak multikolinier \\
\hline
\end{tabular}

Berdasarkan tabel di atas hasil uji multikolonieritas antar variabel

menunjukkan bahwa interkorelasi antar variabel mempunyai harga lebih kecil dari 0,800, ini berarti tidak terjadi multikolonieritas antar variabel bebas sehingga dapat dilanjutkan uji berikutnya.

\section{Uji Hipotesis}

Hipotesis merupakan jawaban sementara atas permasalahan yang dirumuskan. Oleh sebab itu, jawaban sementara harus diuji kebenarannya secara empirik. Pengujian hipotesis dalam penelitian ini dilakukan dengan menggunakan analisis regresi sederhana dengan melihat nilai t hitung pada output yang dihasilkan oleh program SPSS versi 16.0. Kriteria yang digunakan $\mathrm{t}$ hitung lebih besar dari t tabel, maka dapat disimpulkan terdapat pengaruh signifikan variabel bebas dengan variabel terikat. Uji t digunakan untuk menguji hipotesis pertama dan kedua. Pengujian hipotesis dalam penelitian ini dilakukan dengan menggunakan teknik analisis regresi linier sederhana untuk hipotesis I dan hipotesis II, dan untuk menguji hipotesis III digunakan analisis regresi ganda.

\section{a. Uji Hipotesis I}

Hipotesis pertama menyatakan terdapat pengaruh positif Sertifikasi Guru $\left(\mathrm{X}_{1}\right)$ terhadap Kinerja Guru (Y) SMA Negeri I Sentolo Kabupaten Kulon Progo Tahun 2012.

Tabel 3. Hasil Analisis Regresi $\left(\mathrm{X}_{1}\right)$ terhadap (Y)

\begin{tabular}{|l|l|l|l|l|l|l|}
\hline \multirow{2}{*}{ Variabel } & \multicolumn{2}{|c|}{$\begin{array}{l}\text { Unstrandardized } \\
\text { Coneficients }\end{array}$} & \multirow{2}{*}{$\mathrm{T}$} & Sig. & $\mathrm{r}$ & $\mathrm{r}^{2}$ \\
\cline { 2 - 4 } & $\mathrm{B}$ & Std. Error & & & & \\
\hline Konstanta & 30,436 & 8,442 & 3,605 & 0,001 & & \\
\hline $\mathrm{X}_{1}$ & 0,478 & 0,163 & 2,952 & 0,005 & 0,410 & 0,168 \\
\hline
\end{tabular}


Berdasarkan tabel di atas dapat diketahui bahwa terdapat pengaruh Sertifikasi Guru dengan Kinerja Guru, hal ini ditunjukkan dari nilai $r$ hitung 0,410. Dengan nilai $r$ tidak terdapat tanda negatif berarti bahwa pengaruh Sertifikasi Guru terhadap Kinerja Guru itu positif. Besarnya pengaruh Sertifikasi Guru terhadap Kinerja Guru dapat dilihat nilai Koefisien Determinan $\left(\mathrm{r}^{2}\right)$ sebesar 0,168 , hal ini berarti bahwa pengaruh antara Sertifikasi Guru dengan Kinerja Guru adalah 16,8\% sedangkan sisanya dipengaruhi faktor-faktor lain.

Persamaan garis regresi dapat diketahui dari besarnya harga koefisien (a) sebesar 0,478 dan nilai konstantanya sebesar 30,436, dengan demikian dapat disusun persamaan garis regresi sederhana sebagai berikut $\mathrm{Y}=30,436+0,478 \mathrm{X}_{1}$

Untuk menguji signifikansi konstanta dilakukan uji t, setelah dilakukan uji t diperoleh harga t hitung 2,952 dan t tabel pada taraf signifikansi 5\% harga nilai t tabel dengan taraf signifikansi 5\% dan $\mathrm{N}=45$ sebesar 1,99. Hasil ini menunjukkan bahwa t hitung lebih besar daripada $\mathrm{r}$ tabel $(2,952>1,99)$ dan probabilitas t hitung lebih kecil dari $5 \%(0,005<0,05)$. Berarti pengaruh Sertifikasi Guru dengan Kinerja Guru signifikan.

Dari perhitungan di atas maka dapat dikatakan bahwa terdapat pengaruh positif dan signifikan Sertifikasi Guru terhadap Kinerja Guru SMA Negeri 1 Sentolo Kabupaten Kulon Progo diterima.

\section{Uji Hipotesis II}

Hipotesis yang kedua menyatakan terdapat pengaruh positif Motivasi Kerja Guru $\left(X_{2}\right)$ terhadap Kinerja Guru (Y) SMA Negeri I Sentolo Kabupaten Kulon Progo Tahun 2012.

Tabel 4. Rangkuman Hasil Regresi $\mathrm{X}_{2}$ Terhadap Y

\begin{tabular}{|l|l|l|l|l|l|l|}
\hline \multirow{2}{*}{ Variabel } & \multicolumn{2}{|l|}{$\begin{array}{l}\text { Unstrandardized } \\
\text { Coneficients }\end{array}$} & \multirow{2}{*}{$\mathrm{T}$} & Sig. & $\mathrm{r}$ & $\mathrm{r}^{2}$ \\
\cline { 2 - 4 } & $\mathrm{B}$ & Std. Error & & & & \\
\hline Konstanta & 17,404 & 9,100 & 1,913 & 0,062 & & \\
\hline $\mathrm{X}_{2}$ & 0,711 & 1,170 & 4,173 & 0,000 & 0,537 & 0,288 \\
\hline
\end{tabular}

Berdasarkan tabel di atas dapat diketahui bahwa terdapat pengaruh Motivasi Kerja Guru terhadap Kinerja Guru, hal ini ditunjukkan dari nilai $r$ hitung 0,537. Dengan nilai $r$ tidak terdapat tanda negatif berarti bahwa pengaruh Motivasi Kerja Guru terhadap Kinerja Guru itu positif. Besarnya pengaruh Sertifikasi Guru terhadap Kinerja Guru dapat dilihat nilai 
Koefisien Determinan $\left(\mathrm{r}^{2}\right)$ sebesar 0,288, hal ini berarti bahwa pengaruh Sertifikasi Guru dengan Kinerja Guru adalah 28,8\% sedangkan sisanya dipengaruhi faktor-faktor lain.

Persamaan garis regresi dapat diketahui dari besarnya harga koefisien (a) sebesar 0,711 dan nilai konstantanya sebesar17,404, dengan demikian dapat disusun persamaan garis regresi sederhana sebagai berikut $\mathrm{Y}=17,404+0,711 \mathrm{X}_{2}$

Untuk menguji signifikansi konstanta dilakukan uji t, setelah dilakukan uji t diperoleh harga $\mathrm{t}$ hitung 4,173 dan $\mathrm{t}$ tabel pada taraf signifikansi 5\% harga nilai t tabel dengan taraf signifikansi 5\% dan $\mathrm{N}=45$ sebesar 1,99. Hasil ini menunjukkan bahwa t hitung lebih besar daripada $\mathrm{r}$ tabel $(4,173>1,99)$ dan probabilitas t hitug lebih kecil dari $5 \%(0,000<0,05)$. Berarti pengaruh Motivasi Kerja Guru terhadap Kinerja Guru signifikan.

Dari perhitungan di atas maka dapat dikatakan bahwa terdapat pengaruh positif dan signifikan Motivasi Kerja Guru terhadap Kinerja Guru SMA Negeri 1 Sentolo Kabupaten Kulon Progo.

\section{Uji Hipotesis III}

Hipotesis ketiga menyatakan terdapat pengaruh positif Sertifikasi Guru $\left(\mathrm{X}_{1}\right)$ dan Motivasi Kerja Guru $\left(\mathrm{X}_{2}\right)$ terhadap Kinerja Guru (Y) SMA Negeri I Sentolo Kabupaten Kulon Progo Tahun 2012. Untuk menguji hipotesis tersebut menggunakan teknik analisis regresi ganda dengan bantuan SPSS versi 16.0. Ringkasan hasil regresi ganda dapat dilihat dalam tabel berikut ini.

\section{a. Persamaan Regresi}

Berdasarkan tabel di atas, maka model persamaan regresi adalah sebagai berikut :

$$
\mathrm{Y}=12,843+0,216 \mathrm{X}_{1}+0,586 \mathrm{X}_{2}
$$

Persamaan tersebut menunujukkan bahwa nilai koefisien $\mathrm{X}_{1}$ sebesar 0,216 artinya apabila nilai Sertifikasi Guru $\left(\mathrm{X}_{1}\right)$ meningkat 1 poin maka nilai Kinerja Guru (Y) akan meningkat sebesar 0,216 poin, dengan asumsi $\mathrm{X}_{2}$ tetap. Koefisien 0,586 $\mathrm{X}_{2}$ artinya jika ada peningkatan Sertifikasi Guru sebesar 1 poin dengan asumsi Sertifikasi Guru, Motivasi Kerja Guru tetap, maka akan ada peningkatan Kinerja Guru sebesar 0,586 poin.

\section{b. Koefisien Determinan $\left(\mathbf{R}^{2}\right)$}

Berdasarkan hasil analisis regresi ganda diketahui bahwa nilai Koefisien Determinan $\left(\mathrm{R}^{2}\right)$ sebesar 0,314, ini menunjukkan bahwa sebesar 31,4\% Kinerja Guru diterangkan oleh 2 faktor yaitu Sertifikasi Guru dan Motivasi Kerja Guru, sedangkan 68,6\% diterangkan oleh faktor lain yang tidak dibahas dalam penelitian ini. 


\section{c. Keberartian Koefisien Regresi Ganda}

Hasil analisis menunjukkan bahwa koefisien korelasi (R) sebesar 0,560 hal ini berarti memang ada pengaruh Sertifikasi Guru dan Motivasi Kerja Guru terhadap Kinerja Guru. Untuk mengetahui signifikansi regresi ganda menggunakan uji F. Pengujian signifikansi untuk mengetahui keberartian variabel Sertifikasi Guru dan Motivasi Kerja Guru secara bersama-sama berpengaruh terhadap Kinerja Guru. Kriteria yang digunakan adalah jika harga $\mathrm{F}$ hitung lebih besar dari nilai $\mathrm{F}$ tabel pada taraf signifikan 5\% dan nilai probabilitas $\mathrm{F}$ hitung lebih kecil $0,05 \%$ berarti prediktor berpengaruh signifikan terhadap kriterium.

Berdasarkan hasil uji yang diperoleh harga $F$ sebesar 9,603 dengan nilai probabilitas 0,000, sedangkan harga $\mathrm{F}$ tabel adalah 3,09 hal ini menunjukkan bahwa harga $\mathrm{F}$ hitung lebih besar dari F tabel $(9,603>3,09)$ dan nilai probabilitas F hitung lebih kecil dari 0,05 $(0,000<$ 0,05) sehingga Sertifikasi Guru dan Motivasi Kerja Guru mempunyai pengaruh positif dan signifikan secara bersama-sama terhadap Kinerja Guru SMA Negeri 1 Sentolo Kabupaten Kulon Progo.

\section{d. Sumbangan Efektif (SE\%) dan Sumbangan Relatif (SR\%)}

Berdasarkan hasil analisis regresi ganda dapat diketahui besarnya Sumbangan Relatif dan Sumbangan Efektif masing-masing variabel bebas terhadap variabel terikat. Besarnya Sumbangan Relatif dan Sumbangan Efektif dapat dilihat pada tabel berikut ini.

Tabel 5. Sumbangan Relatif dan Sumbangan Efektif Variabel Bebas terhadap Variabel Terikat

\begin{tabular}{|l|l|l|}
\hline \hline Nama Variabel Bebas & $\begin{array}{l}\text { Sumbangan Relatif } \\
(\%)\end{array}$ & $\begin{array}{l}\text { Sumbangan } \\
\text { Efektif }(\%)\end{array}$ \\
\hline Sertifikasi Guru & 24.29 & 7.62 \\
Motivasi Kerja Guru & 75.71 & 23.75 \\
\hline Jumlah & 100.00 & 31.38 \\
\hline
\end{tabular}

Berdasarkan hasil analisis yang tercantum dalam tabel di atas dapat diketahui bahwa Sertifikasi Guru memberikan sumbangan relatif 24,29\% dan Motivasi Kerja Guru sebesar 75,71\%. Sumbangan efektif variabel Sertifikasi Guru sbesar 7,62\% dan Motivasi Kerja Guru sebesar 23,75\%. Sumbangan efektif total sebesar 31,38\% yang berarti secara bersama-sama variabel Sertifikasi Guru dan Motivasi Kerja Guru memberikan sumbangan efektif sebesar 
$31,38 \%$ sedangkan $68,62 \%$ diberikan oleh variabel-variabel lain yang tidak dibahas dalam penelitian ini.

Penelitian ini bertujuan untuk mengetahui pengaruh Sertifikasi Guru dan Motivasi Kerja Guru Terhadap Kinerja Guru SMA Negeri 1 Sentolo Kabupaten Kulon Progo Tahun 2012. Berdasarkan data penelitian yang dianalisis maka dilakukan pembahasan tentang hasil penelitian sebagai berikut.

1. Pengaruh Sertifikasi Guru Terhadap Kinerja Guru SMA Negeri 1 Sentolo Kabupaten Kulon Progo Tahun 2012

Hasil penelitian menunjukkan bahwa terdapat pengaruh positif dan signifikan Sertifikasi Guru terhadap Kinerja Guru SMA Negeri 1 Sentolo Kabupaten Kulon Progo Tahun 2012. Hal ini dibuktikan dari hasil uji t diperoeh nilai t 2,952 dengan probabilitas 0,005 dan harga $t$ tabel sebesar 1,99 dengan $\mathrm{N}=45$ pada taraf signifikan $5 \%$.

Dari penjelasan di atas dapat disimpulkan bahwa variabel Sertifikasi Guru $\left(\mathrm{X}_{1}\right)$ mempunyai pengaruh yang positif dan signifikan terhadap Kinerja Guru (Y). Dengan demikian dapat dikataka bahwa semakin positif Sertifikasi Guru, maka Kinerja Guru akan semakin tinggi pula. Sebaliknya jika Sertifikasi Guru negatif, maka Kinerja Guru semakin rendah.

Dari analisis juga diperoleh koefisien regresi $r_{x 1 y}$ sebesar 0,410 dan koefisien determinasi $\left(\mathrm{r}^{2}\right)$ sebesar 0,168 . Berdasarkan nilai tersebut dapat diartikan 16,8\% dari variabel Kinerja Guru (Y) dapat dipengaruhi oleh variabel Sertifikasi Guru $\left(\mathrm{X}_{1}\right)$, sedangkan sisanya sebesar $83,2 \%$ dijelaskan oleh variabel lain.

Besarnya sumbangan efektif Sertifikasi Guru terhadap Kinerja Guru yaitu sebesar 7,62\%, dengan demikian dapat dikatakan bahwa semakin baik Sertifikasi Guru akan semakin tinggi pula Kinerja Guru yang dicapai. Hal ini didasari oleh pendapat Yamin (2010) bahwa terdapat faktor-faktor yang mempengaruhi kinerja guru, salah satunya yaitu faktor kontekstual (situsional), meliputi tekanan dan perubahan lingkungan eksternal (sertifikasi guru).

2. Pengaruh Motivasi Kerja Guru terhadap Kinerja Guru SMA Negeri 1 Sentolo Kabupaten Kulon Progo Tahun 2012.

Berdasarkan hasil analisis menunjukkan bahwa terdapat pengaruh yang positif dan signifikan antara Motivasi Kerja Guru terhadap Kinerja Guru SMA Negeri 1 Sentolo Kabupaten Kulon Progo Tahun 2012. Hal ini dibuktikan dari hasil uji t diperoeh nilai t 4,173 
dengan probabilitas 0,000 dan harga t tabel sebesar 1,99 dengan $\mathrm{N}=45$ pada taraf signifikan $5 \%$.

Dari penjelasan di atas dapat disimpulkan bahwa variabel Motivasi Kerja Guru $\left(\mathrm{X}_{2}\right)$ mempunyai pengaruh yang positif dan signifikan terhadap Kinerja Guru (Y). Dengan demikian dapat dikatakan bahwa semakin tinggi Motivasi Kerja Guru, maka Kinerja Guru akan semakin tinggi pula. Sebaliknya jika Motivasi Kerja Guru negatif, maka Kinerja Guru semakin rendah.

Dari analisis juga diperoleh koefisien regresi $r_{x 1 y}$ sebesar 0,537 dan koefisien determinasi $\left(\mathrm{r}^{2}\right)$ sebesar 0,288. Berdasarkan nilai tersebut dapat diartikan 28,8\% dari variabel Kinerja Guru (Y) dapat dipengaruhi oleh variabel Motivasi Kerja Guru $\left(\mathrm{X}_{2}\right)$, sedangkan sisanya sebesar $71,2 \%$ dijelaskan oleh variabel lain.

Besarnya sumbangan efektif Motivasi Kerja Guru terhadap Kinerja Guru yaitu sebesar 23,75\%, dengan demikian dapat dikatakan bahwa semakin tinggi Motivasi Kerja Guru akan semakin tinggi pula Kinerja Guru yang dicapai. Hal tersebut didasari oleh pendapat Yamin (2010) bahwa terdapat faktor-faktor yang mempengaruhi kinerja guru, salah satunya yaitu faktor personal atau individual, meliputi unsur pengetahuan, keterampilan, kemampuan, kepercayaan diri, motivasi dan komitmen yang dimiliki oleh tiap individu guru. Menurut Manullang (2006) bahwa motivasi kerja tidak lain dari sesuatu yang menimbulkan dorongan atau semangat kerja.

3. Pengaruh Sertifikasi Guru dan Motivasi Kerja Guru terhadap Kinerja Guru SMA Negeri 1 Sentolo Kabupaten Kulon Progo Tahun 2012.

Hasil pengujian hipotesis ketiga menunjukkan adanya pengaruh positif dan signifikan antara Sertifikasi Guru dan Motivasi Kerja Guru terhadap Kinerja Guru SMA Negeri 1 Sentolo Kabupaten Kulon Progo Tahun 2012. Hal ini dibuktikan dengan nilai F hitung > F tabel untuk taraf signifikan $5 \%$ yaitu sebesar $(9,603>3,09)$ dan nilai probabilitas hitung lebih kecil dari 0,05 (0,000 >0,05), maka dapat disimpulkan bahwa memang terdapat pengaruh positif dan signifikan Sertifikasi Guru dan Motivasi Kerja Guru terhadap Kinerja Guru SMA Negeri 1 Sentolo Kabupaten Kulon Progo Tahun 2012. Pengaruh tersebut ditunjukkan dengan Koefisien Determinan $\left(\mathrm{R}^{2}\right)$ sebesar 0,314. Ini berarti bahwa 31,4\% Kinerja Guru SMA Negeri 1Sentolo dipengaruhi oleh Sertifikasi Guru dan Motivasi Kerja Guru sedangkan 68,6\% dipengaruhi faktor lain yang tidak dianalisis dalam penelitian ini. 
Hasil penelitian ini didasari teori yang dikemukakan oleh Yamin (2010), faktor yang mempengaruhi Kinerja Guru terdiri dari faktor internal dan faktor eksternal. Salah satu faktor internal yaitu motivasi, sedangkan salah satu faktor eksternal adalah Sertifikasi Guru.

\section{Penutup}

Berdasarkan data yang diperoleh dari hasil penelitian yang dilakukan maka dapat ditarik kesimpulan sebagai berikut :

1. Terdapat pengaruh positif dan signifikan Sertifikasi Guru Terhadap Kinerja Guru SMA Negeri 1 Sentolo Kabupaten Kulon Progo Tahun 2012 yang ditunjukkan dengan Persamaan garis regresi dapat diketahui dari besarnya harga koefisien (a) sebesar 0,478 dan nilai konstantanya sebesar 30,436, dengan demikian dapat disusun persamaan garis regresi sederhana sebagai berikut.

$$
\mathrm{Y}=30,436+0,478 \mathrm{X}_{1}
$$

Nilai thitung lebih besar dari t tabel dan $\mathrm{N}=45$ pada taraf signifikansi $5 \%$ yaitu sebesar $(2,952>1,99)$ dan nilai probabilitas t hitung lebih kecil dari $0,05(0,005<0,05)$. Dari analisis juga diperoleh koefisien regresi $r_{x 1 y}$ sebesar 0,410 dan koefisien determinasi $r^{2}$ sebesar 0,168. Berdasarkan nilai tersebut dapat diartikan 16,8\% dari variabel Kinerja Guru (Y) dapat dipengaruhi oleh variabel Sertifikasi Guru $\left(\mathrm{X}_{1}\right)$, sedangkan sisanya sebesar $83,2 \%$ dijelaskan oleh variabel lain yang tidak dijelaskan dalam penelitian ini.

2. Terdapat pengaruh positif dan signifikan Motivasi Kerja Guru Terhadap Kinerja Guru SMA Negeri 1 Sentolo Kabupaten Kulon Progo Tahun 2012 yang ditunjukkan dengan Persamaan garis regresi dapat diketahui dari besarnya harga koefisien (a) sebesar 0,711 dan nilai konstantanya sebesar17,404, dengan demikian dapat disusun persamaan garis regresi sederhana sebagai berikut.

$$
\mathrm{Y}=17,404+0,711 \mathrm{X}_{2}
$$

Nilai thitung lebih besar dari t tabel dan $\mathrm{N}=45$ pada taraf signifikansi $5 \%$ yaitu sebesar $(4,173>1,99)$ dan nilai probabilitas $t$ hitung lebih kecil dari $0,05(0,000<0,05)$. Dari analisis juga diperoleh koefisien regresi $\mathrm{r}_{\mathrm{x} 2 \mathrm{y}}$ sebesar 0,537 dan koefisien determinasi $\mathrm{r}^{2}$ sebesar 0,288. Berdasarkan nilai tersebut dapat diartikan 28,8\% dari variabel Kinerja Guru (Y) dapat dipengaruhi oleh variabel Motivasi Kerja Guru $\left(\mathrm{X}_{2}\right)$, sedangkan sisanya sebesar $71,2 \%$ dijelaskan oeh variabel lain yang tidak dijelaskan dalam penelitian ini. 
3. Terdapat pengaruh positif dan signifikan Sertifikasi Guru dan Motivasi Kerja Guru secara bersama-sama terhadap Kinerja Guru SMA Negeri 1 Sentolo Kabupaten Kulon Progo Tahun 2012 yang ditunjukkan dengan persamaan regresi adalah sebagai berikut :

$$
\mathrm{Y}=12,843+0,216 \mathrm{X}_{1}+0,586 \mathrm{X}_{2}
$$

Nilai F hitung > F tabel untuk taraf signifikansi 5\% yaitu sebesar $(12,843>3,09)$. Dari analisis juga diperoleh koefisien regresi $r_{x 1 y}$ sebesar 0,560 dan koefisien determinasi $R^{2}$ sebesar 0,314. Berdasarkan nilai tersebut dapat diartikan 31,4\% dari variabel Kinerja Guru (Y) dapat dipengaruhi oleh variabel Sertifikasi Guru ( $\left.\mathrm{X}_{1}\right)$ dan Motivasi Kerja Guru $\left(\mathrm{X}_{2}\right)$, sedangkan sisanya sebesar $68,8 \%$ dijelaskan oleh variabel lain yang tidak dijelaskan dalam penelitian ini.

\section{E. Daftar Pustaka}

Manullang, Marihot. (2006). Manajemen Personalia.Yogyakarta : Gadjah Mada University Press.

Martinis Yamin dan Maisah. (2010). Standarisasi Kinerja Guru. Jakarta: Gaung Persada Press.

Sugiyono.(2008). Metode Penelitian Pendidikan Pendekatan Kuantitatif, Kualitatif, dan $R \& D$. Bandung: CV. Alfabeta. 